\title{
Effects of Multiple Nozdes on Asymmetric Ejector Performance
}

\author{
D. Linoberry" and Dr. B. Landrum ${ }^{\dagger}$

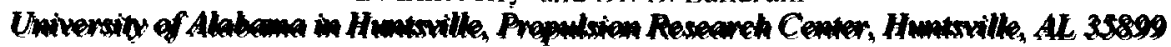

This paper presents a comparison of a ingle nozgle and a dual nongle strut based ejector. The results are

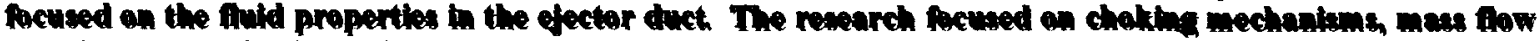
entralnment, and mixing duct prensure diatributions. The two ejector wore tested at equivalent primary

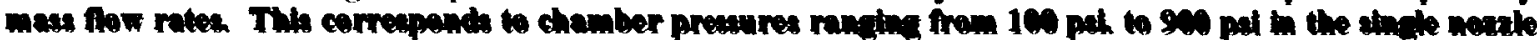
strut and $50 \mathrm{pal}$ to $460 \mathrm{pol}$ in the dual noasle atrut. Secondary flow was drawn from the lab at atmoupherte pressure, and was mat centrolled The secendary fow was found to choke at a value of 2.3 ther hr a prtmary mass flow rate of approximately $2.1 \mathrm{lb} / \mathrm{s}$ for both ejectors. Thts choke was bolloved to be a mass addition

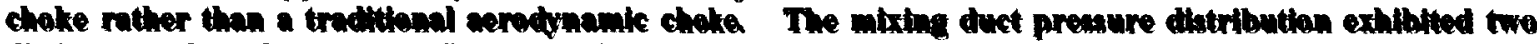
distinct trends "low pressure" trend and " "high pressure" trend. For the low presuure trend, the mixing

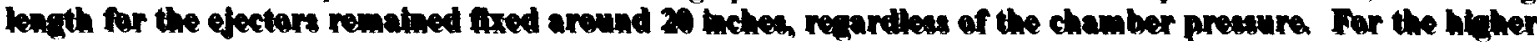
presure trend, the mixing length wes considerably longer and Increased with tacreasing chamber pressure.

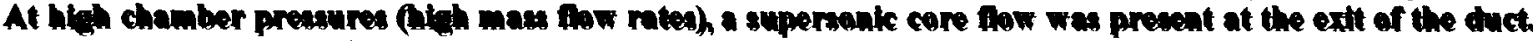
For these cases, the two now streams did not have time to mix by the end of the duct.

Nomencleture

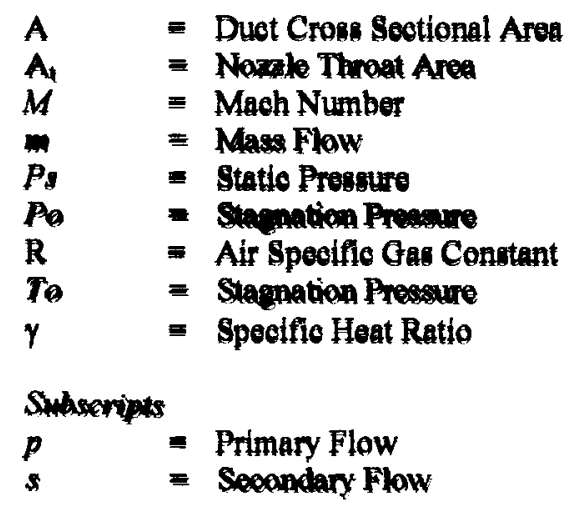

\section{Introduction}

Combinad Cyele Propulaion (CCP) tobnology hows promise for next genoration launoh vehioles" Sinoe a combined oycle encine ineorporates ceveral modes of engine operation into the seme flow path the optimum performance mode on be utilined in cach fligh rejime A typioal Roeket Based Combined Cyele (RBCC) ongine would operate in a rocket or duoted rooket mode for takeoff and initial acceleration to about Mach 2-3,

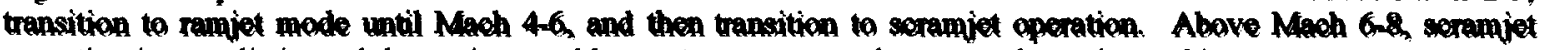
operation is unrealigtio, and the engine would operate as a pure rocket to accelerate into orbit.

\footnotetext{
"Oraduate Remearch Asdintant, Meohanical and Aorospace Engineoring Dopartment, 8225 Teohnology Hall, Huntsville Al, 35899, Student Momber

Profesaor, Mechanionl and Aeroppece Engineering Depertment, S225 Technology Hall, Hunteville, Al, 35899, AIAA Fullow. Associoze Fellow (?)
}

This material is doolared a work of the U.S. Govornment and is not eubjoct to copyright protection in the United States 
The Strutiot is one of the RBCC gyatems under consideration. This engine canaista of a variable geometry duat with vertical engine strut mounted internally. Bach strut has several roeket nozzles embedded within it. The

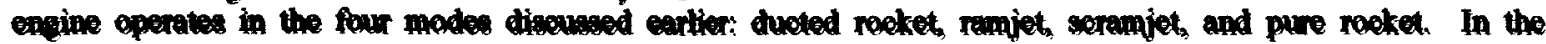
airbreathing modes, atmonphorio air in ingented into the inlot and flows botween the struts into the mixing moetion. The air axidiner is mixed with the fued rioh roket exhaust and combusted. The combustion produets are aceeterated through an exit nozzle to provide the thruat.

A fundamental undertanding of ejector physios is an enabling rochnoloy to realize an operational RBCC propulnion syatem. Pant thooretioal and experimental ojector otudies have considered one-dimensional, axisymmetrie, of at best twodimensional gecmetrie Conoepts sueh the strujet use a complex asymmetrie, three-dimensional flow path. The University of Alabama in Huntrville (UAH) Propulaton Research Center (PRC) has an angin researeh proeram to charecterize asymmetrie ejector perfermance in terms of mass fow entrainment and atream mixing. This study wll holp guide denign of future RBCC systems and provide valuable data for validating computational fhuid dynamie simulations of complex ejector systems.

\section{Facllty Deacription}

The UAH FRC cold flow ejeetor feeility was originally deaigned to appraximate the flow path of the Aerojet Strutjet concept. As ahown sohematically in Figure 1, the flow path consiats of a rectangular cross seotion dust $4.5 \mathrm{in}$. wide by 3 in, tall. An elliptically contoured converging inlet is locatod on the front ond of the duot to provide uniform airlow from the laboratony. A single snt is inatalled in the duet appraximately 25 inehes downstrean of the inlet. The PRC has been experimenting with two otrute, a ingle nozzle strut and a dual nozzle strut. The struth, shown in Fig. 2. have identical reetangular soctions 1 ineh wide 7 inches tall. Rocket norales are enbedded in the struts to provide the primary flow stream for the gystem. These nozzles have identical geometries with area ratios of appraximately 466 and transition them a cireular throat to a square exit. The dual noxale sunt also has a turbine exhaust alit approximately 0.094 in wide located botween the two rocket nozzlos. For this gories of tenting, tho alit was not utilized, and was therefore flled.

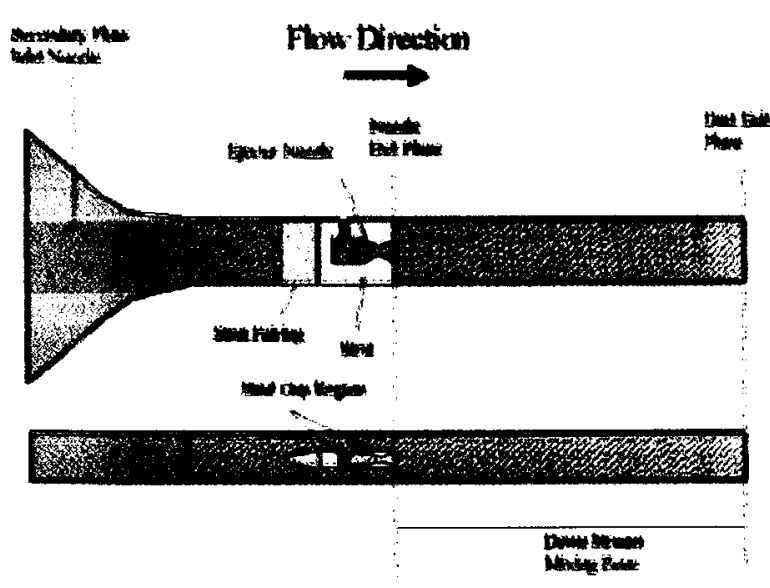

Flqure 1. UAH Strut Ejectar Fow Path (Not to Seale)

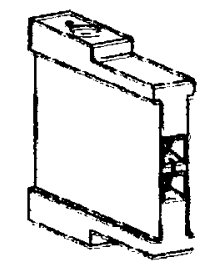
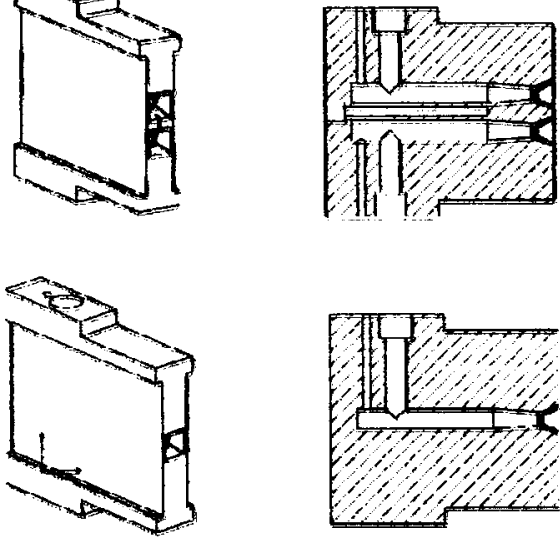

Furve 2. CAD Drawteng of Dud and stagle Nozzle struts

The PRC ejector fecility is shown in Fin. 3. The faility censists of two air tanks with a combined vahme of 524 cubie feet, 1.25 in. stainlens steel supply tubing, a PID controller to regulate chamber prenenre, and the duet. A single strut is installed in the duet for a pertieular test. The duet exits into a cantant area shoet metal difiuser that is open to the laboratory. An array of 48 statio prennure tapn are located along the centerlines of the top and aide walln of the duet. The taps are speced 0.5 inehes apart for the first 10 inehes, and 1.0 inch apart for 28 inehes that follow. Ten statio pressure taps are located on the centerline of the aidowall in the strut gap region of the duet. This region is located upstrean of the reoket nowle exit plane between the strut and the sidewall of the duet (see Finure 1). An aerodynamic fairing in located on the uputream end of the atrut to provide uniform flow in the atrut gap region. A Piton-statio probe is embedied in this fuiring to measure the stapnation and statio presure of the secondary (indueed) flow. A Pitot-ntatie probe in aleo loeated at the exit plane of the duot. Thin probe meanures the atagnation and the 
atatic pressure of the preaumed fully mixed flow at the exit of the duct. The probe in mounted to a trevering mechanirm, so the presiure can be recorded at vartous positions coross the oxit plane.

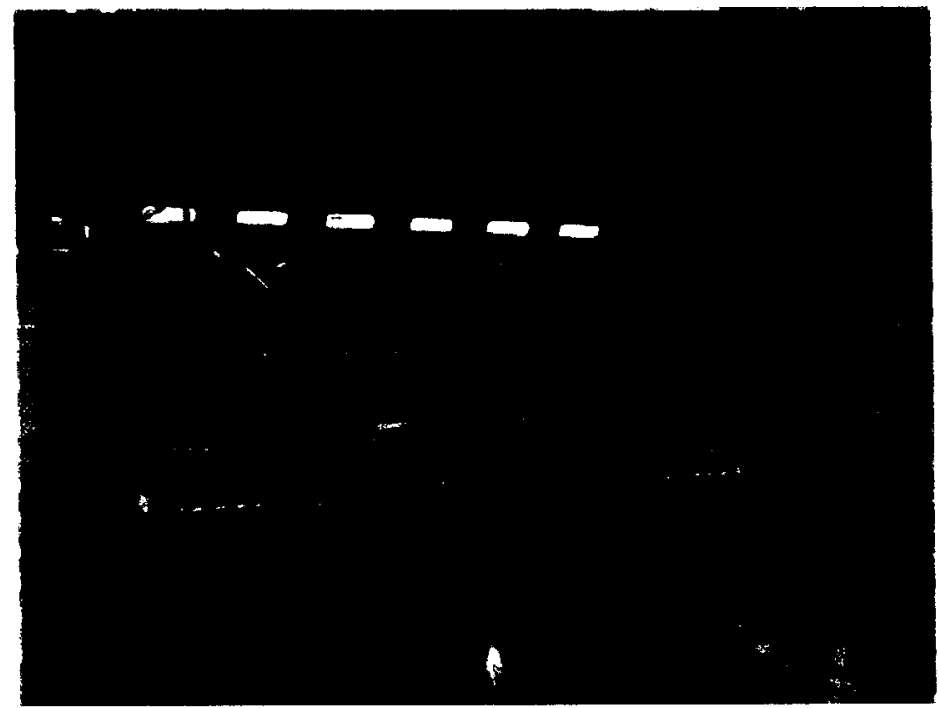

Thure 2. UAH PRC Ejector Factity

A preseure tap in aleo loeated in the chamber of the rocket nozzle to measure the chamber preneure of the rocket.

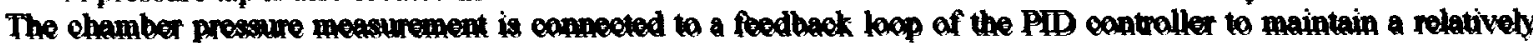
constant chamber preseure for the experiment. In addition to the preseure instrumentation of the duet, two thermocauples are boated in the duet. One messurs the remperature of the rocket ehamber, and the other measures the temperature of the necondary air atream. An outedde barometer/thermometer is uned to measure the atmonpherio pressure and temperature in the lab at the time of each test.

\section{Prevlous Research}

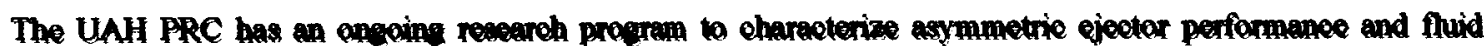
mochanies. The initis sudie were focued on the mixing between the reoket and turbine exhousts with the

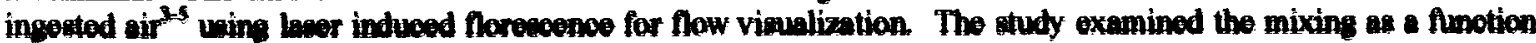
of the ratio of ohamber promare to turbine exhnumt preanure. A oomplimentary atudy was performed to examine the rocket indueed flow field in the reotengular duet for the dual nozzle strut. ${ }^{6}$ The induced airflow as a function of primary roeket how rate was measured. Pitot pressure traverses were used to examine the expansion rate of the rocket and turbine exhaust plumes, and aseess mixing losses. Pressure travernes were aleo made in the atrut gap region where the seopdary llow ohake was believed to coour. At the time of these stutios the instrumentation was limited.

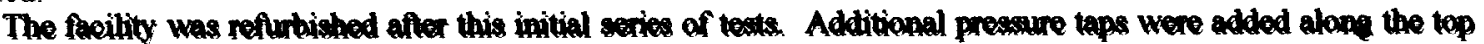
and sidewells of the mixing duot and in the drut gap repion $A$ series of tosts on the single nowzle thut were performed to examine details of the ohoking and mixing proces ${ }^{7}$. This work was reently extended to highor presstres and was presented at the 2003 Joint Propulsion Conference." Roforence 9 ineluded data from a limited number of tests. This paper presents data from additional single nozkle tosts well a complete set of dual nozzle terta.

\section{Teat Procedure}

For each tent merien, the storage tanke are prescurized to 2500 pal to ensure that a complete net of ohamber pressures can be teated. When the tex begins the ehamber presure of the roeket nowle is established at one of the deaired (net) preneuren, and measurements are taken along the duot. When ten meanuremonts of each of the top wall and sidewall pressure taps have been taken the chamber preasure is ramped up or down to the next set pressure. Test have been porformed in stops of inoraaing chamber prensure and in stops of deereasing ehamber prenure to 
asmess any bytecenis effect. For tents examining the mixing duot presare diatribution, the teat is run for a period of time lons enough for 10 measurements to be taken at each of the 48 presure taps along the top and sido wall. $A$ mechanical saeni valve is used to recond prosure measurement at a given tap and then move to the next postion along the mixing duet. Each tests requires approximately 2 minutes of flow time to complete the 10 cyles. For the prosure distribution, mas flow, Mach number, and strut gap presure results, the data presented consist af averege values from ton separate tests. For pressure traverses aorose the exit, traces were taken at five different locations from the centerline to the top wall. The treverses eomist of movenent from the center of the chet to the side wall. The probe was stopped in 11 distinot loations and took 15 mearuroments at enoh otop. This data was then averaged at each position to ereate the plor.

\section{Regult!}

\section{A. Mass How}

For RBCC applications, the secondary flow mase entrainment is a eritical acpeot of the air breathing portions of figh. The mas fow of the secondary air a funetion of chamber presure is eritioal in establishing mixture ratios for engine operation and the amount of onboard oxidizer that will be required. For the ourrent experimental apparatus scomdary mas flow is caleulated from the stamation and statie precures measured by a Pitakstato probe upitream of the strut, and from the inlet temperature of the flow. With the area of the duet at the meaurement locations known the mas flow is caleulated soconding to

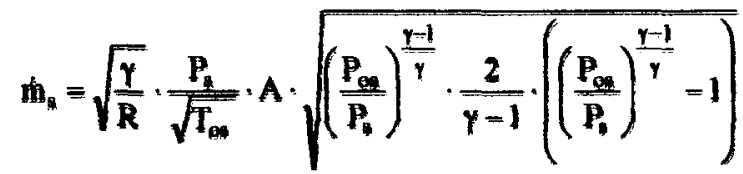

This equation is based on idealized flow. Geometry effect of the rectangular duot inlet are not included. The mas flow of the primary streen is caloulated based on the asumption that the flow is oboked at the throat of the rooket nozzle using the equation

$$
\dot{m}_{p}=\frac{P_{\mathrm{Qp}}}{\sqrt{T_{\mathrm{C}}}} A \sqrt{\frac{\gamma}{R}\left(\frac{2}{y+1}\right)^{\frac{y+1}{\gamma}}}
$$

Where the chamber prescure is apeeiffed for the test, and the chamber temperature in measured by a thermocouple in the rocket ohamber. Finue 4 shows the variation of both primary mas flow and secondary mass llow plotted againgt the chamber preasures for both the ingle and dual nozzle atrut. 


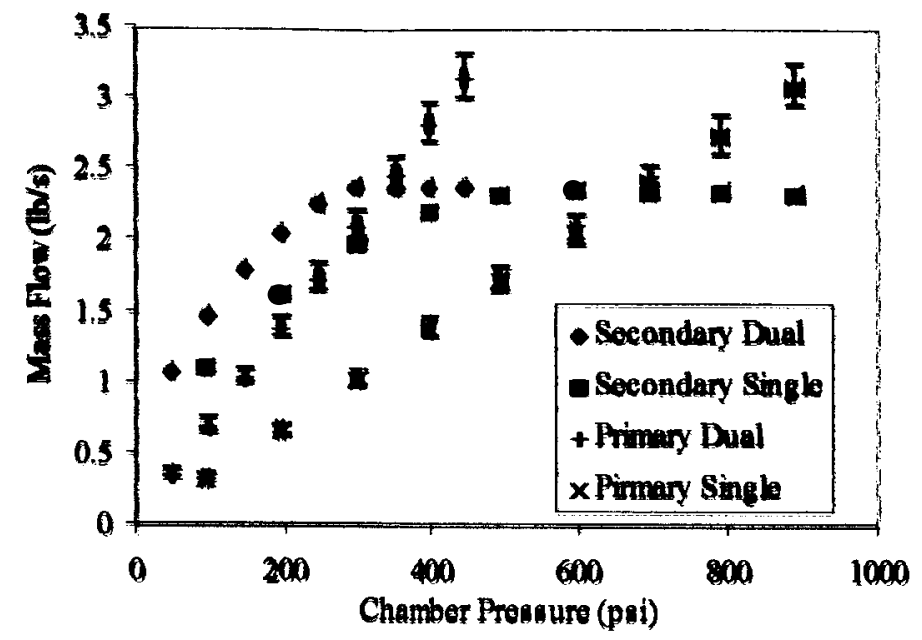

Foure 4 Secenday and Prtmary Man Fow (Dwal and stinde Nowne)

A ean be meen in the flgure, the secondary flow for both the single and dual nozzle appearn to reach a maximum a mass flow of around $2.4 \mathrm{lb} / \mathrm{s}$. For the single nowale this cocurs at a chamber pressure of approximately 600 phi, for the dual nozzle, this oecure around 300 pai. Since the nozzle exit area for the dual nozzle is twice that of the dual nomele the maximum secondary how coours around the same primary mass flow for both atruts. This correnponds to a primary mans flow of appriximately $2.1 \mathrm{lb} / \mathrm{k}$. Thin oan be seen more olearly in Figure 5, which shows the ondary mass flow ploted agianst primary mass now for both nozles.

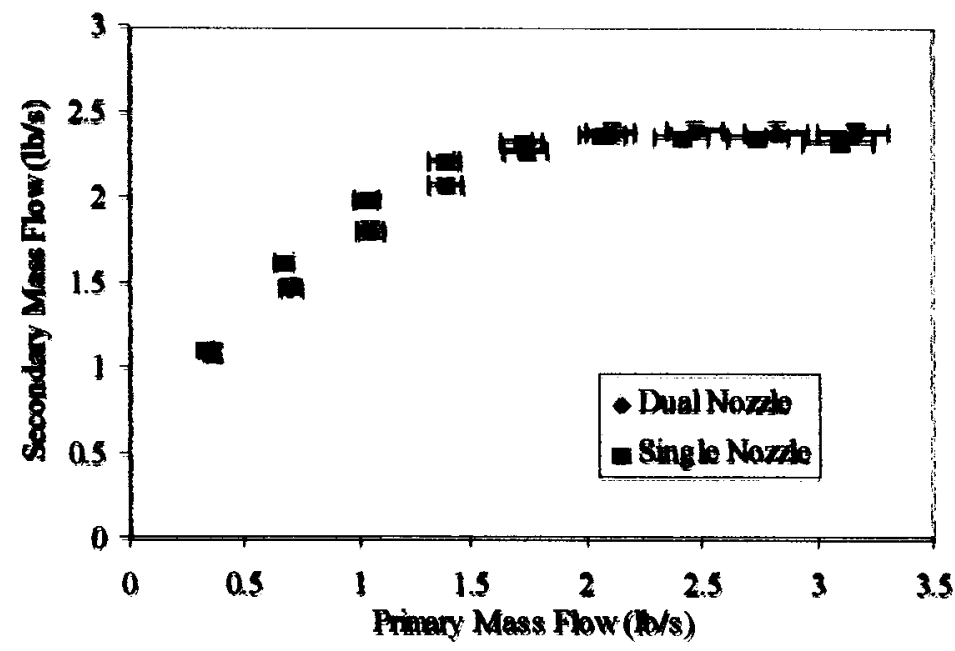

Figure 5 Secondary Mans Flow voraun Primary Masu Flow (Dual and Stande Nomile)

Figure 5 indicates that the maximum secondary mas flow ocoure near the name primary mase flow. This indicates that the mecondary flow is a funotion of momentum rather than exit preasure of the nozzle. The obake

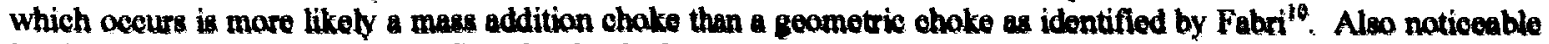
in Figure 5 is that the secondary flew for the dual newale is in general slighty less than that of the single nowale for the name primary mana flow rate until the ohoke is reached. 
Mass flow entrainment is another important paremeter in RBCC applications. This quantity is the amount of secondary flow that can be indueed for a given primary mans flow. Figures 6 and 7 show mass flow entrainment using a parameter called the suction ratio, whioh is caleulated by

$$
=\frac{m_{1}}{m_{p}}
$$

whero $\lambda_{8}$ the secondary mass flow and $\lambda$ the primary mass flow. Figure 6 shows the auction ratio plottod against the ratio of the nonle chamber presure to the secondary flow stagnation pressure (atmaspherie pressure) Figure 7 how the suction ratio plotted against primary masn flow rate.

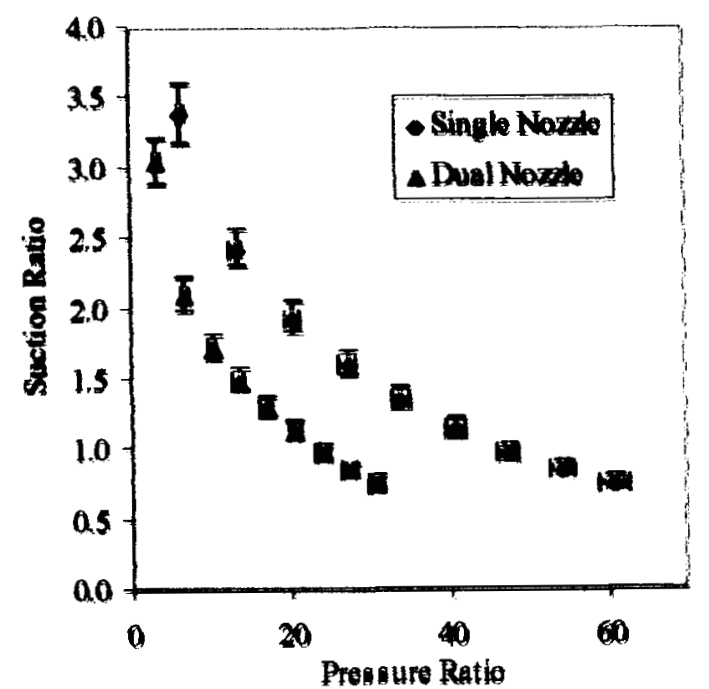

Foure 6 Suction Ratio Versus Presure Rath (Atnglo and Dual Nozules)

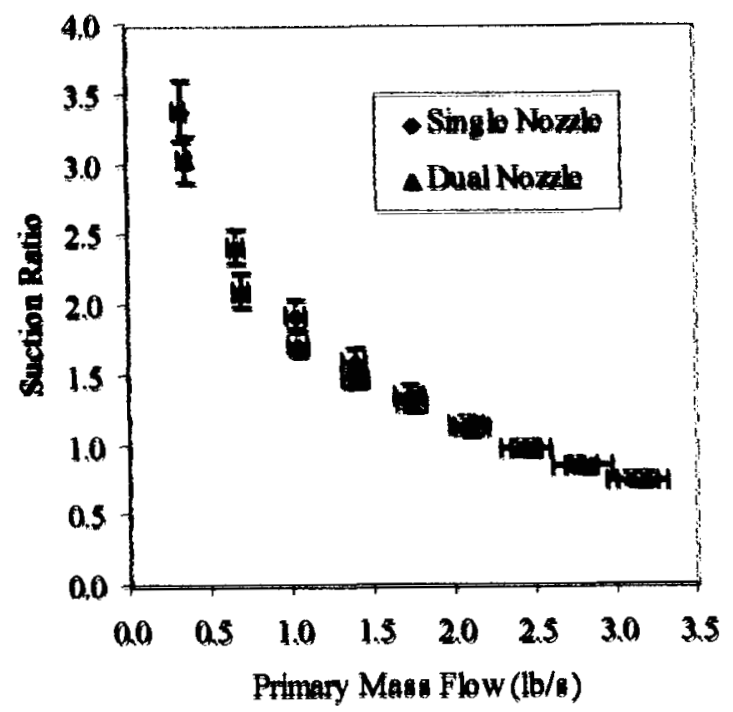

Denure 7 Suction Ratio Veraus Primary Mass Ftow (SInqle and Dunl Nozgles

\section{B. Mach Number}

The Mach number of the mecondary flow upatream of the atrut and the presumed mixed flow at the exit of the dwet were next evaluated. Total and atio presures were measured upstream of the strut for the secondany flaw and in the center of the duet exit for the mixed flow. The resultant Maeh numbers were determined from the ration of the measured total and statie presures. Two separate equations must be used depending on whether the flow is sonie or submonie. For the nubronic flow ahoad of the atrut the Mach number $M$ is caleulated by

$$
M_{s}=\sqrt{\frac{2}{\gamma-1}\left(\left(\frac{P_{o_{A}}}{P_{s}}\right)^{\frac{\gamma-1}{\gamma}}-1\right)}
$$

Where Pos is the stagnation presure measured by the Pitat probe, Ps is the statie presure measured by the probe, and $\gamma$ in the ratio of apeeifle heats (oqual to 1.4 for air).

The duet exit flow enld be subsonic or supersonic. When the flow is subsenie Eq. (4) is used. When the flow is auperanie, then a ahook will form in front of the blunt probe. The atagnation prensure moasured by the probe will

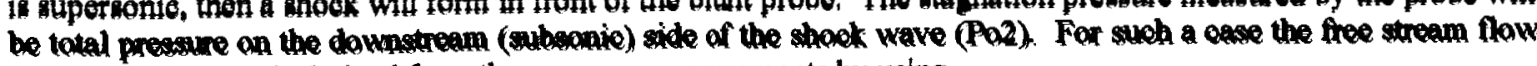
Mach number $\left(\mathrm{M}_{1}\right)$ is dorived from the preanure meanurements by uning 


$$
\frac{P 0_{2}}{R}=\left[1+\frac{2 \gamma}{\gamma+1}\left(M_{1}^{2}-1\right)\right] \cdot\left[1+\frac{\gamma=1}{2}\left(\frac{1+\frac{\gamma=1}{2} M_{1}^{2}}{\gamma \cdot M_{1}^{2}=\frac{\gamma=1}{2}}\right)\right]^{\frac{\gamma}{\gamma-1}}
$$

In this equation $P_{1}$ is a static prosure moesured on the upstream (free experiments, a static preseure on the sidewall of the duet at the oxit plane is uned for the statie prenure, and the stagnation presure is meaured with a pita probe in the eenter of the exit plane. To piok which equation is required, the ratio of the stagnation pressure to statio presnure is determined. If this ratio is lens than 1.89 , then the now is subsonie, and Eq (4) is ued. If the presure ratio is greater than 1.89, then the flow will be sanie, a shook will form in front of the probe, and $\mathrm{Eq}$. (\$) munt be unod.

Figure 8 shows the Mach numbers of the seoondary flow and the mixed flow at the duet exit for beth the single and dual nozzle struts at each of the otudied ohamber prensures. For all tents the secondary flow Maoh number reached a contant value of appraximately 0.28 at a primary chamber presure of appraximately 600 psi for the aingle nozzle strut and a chamber preseure of approximately 300 pai for the dual nozzlo atrut. This is connistent with the secondary mass flow chakin indieated in Figs 4 and 5 . For the single nowle strut, the Mach number at the duet exit inereased to a value of approximately 0.625 where it began to lovel off around a chamber proaure of 600 pail.

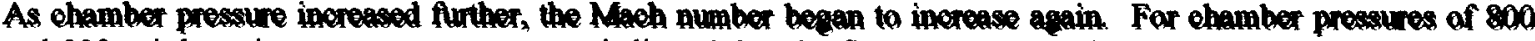
and 900 pai the exit preseure measuroments indicatod that the flow was aupernonic. For the dual nozzle ntrut, the same trend appears. The exit Mach number remains subsonie for ehamber pressures of 350 of lower. Altheugh the data does not appear to lovel off as the single nozzle does, the plot ahowa a jump to auperenic flow for chamber pressures above 400 pai. The mixing duct pressure profiles shoun later will indicate this is beeause the soeondary flow has not fully mixed with the supereonio core of the primary jet at these conditions.

Figure 9 shows the inlet and exit Maeh numbers plotted againat primary mass now: Again as noted eartier, an equivalent primary mass flow for the dual nozzle atrut corresponds to half the chamber pressure in the aingle nozzle

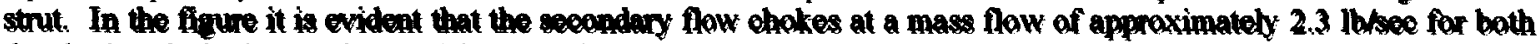
the dual and single nozzle. In Figure 9, it an also be soen that the flow goen from nubmonic to nuporeonie at approximately the same primary mass flow rate. This indicates that the momentum effeots present in the ejector aystem are the driving influme in the flow features and the premure effoets have leas impaet. The highost maoh number reached for the dual nofale flow was appraximately 1.3 , while the highes maeh number for the single nozzle atrut was approximately 1.1 .

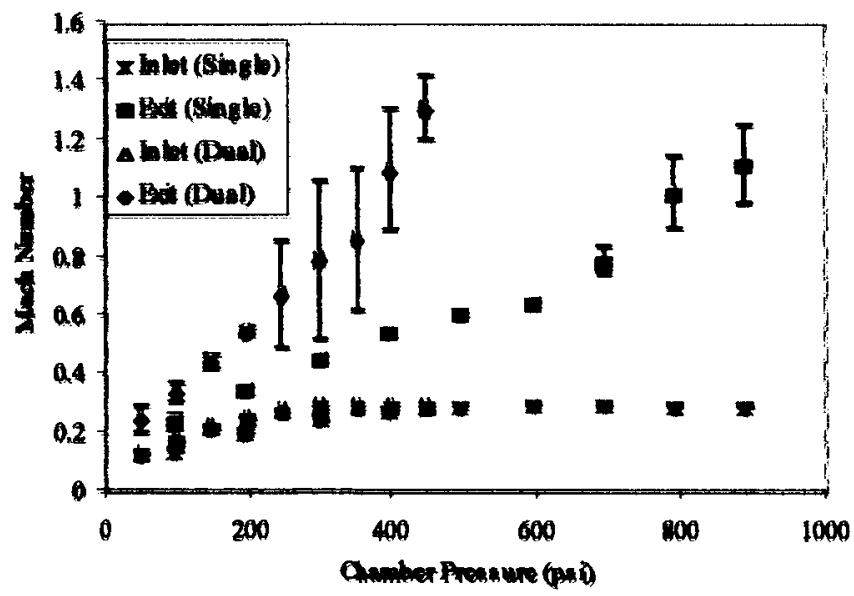

Figure 8 Inlet and Exit Centorline Mach Numbers versus Cramber Preaure (Sinele and Dual Nesules) 


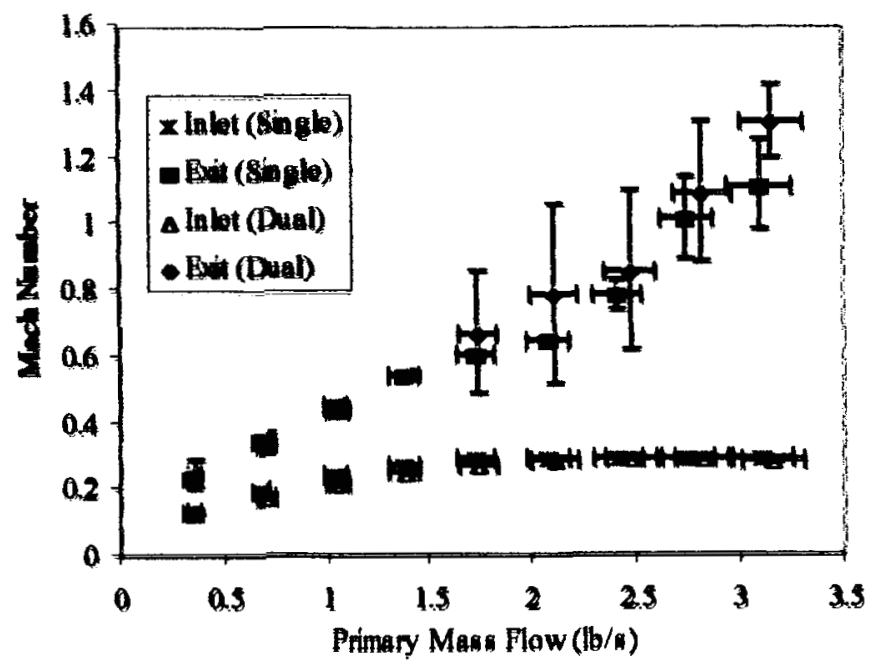

Toure 9 liblet and Exil Centertine Mach Number Veraus Primary Mass Flow (SIngle and Dual Nozzlos)

\section{Strut Gap Presunves}

While the plots of Figuren 4 and 5 and Fifures 8 and 9 indicate that the mecondary flow becomes choked, thene plats do not indionte the type of ehoke whioh oceurs. In a confined ejoctor system like the freility at the PRC there are two primary means of choking the secondary flow as ahown in Fig. 10. When a flow in restristed by a minimum reametrie area (sweh as the throat of a noezlo) it may choke at that point. The maximum mass flow that may pass down the duet is limited to the maximum mase flow that may pass through that restrietion. This type of choke is referred to an an aerodynamie chake. The other type of ohake, a mass addition or Fabri chake ${ }^{10.11}$, is coused by the restricting of the secondary flow between the outer duet wall and the expanding plume of the primary jet. The secondany now is still not fully mixed with the primary now and is ectin independently. The phume baundary as a wall for the secondary flow and the maximum mass flow for the stream in that which ean pass through the area created by the well and the plume boundaries.

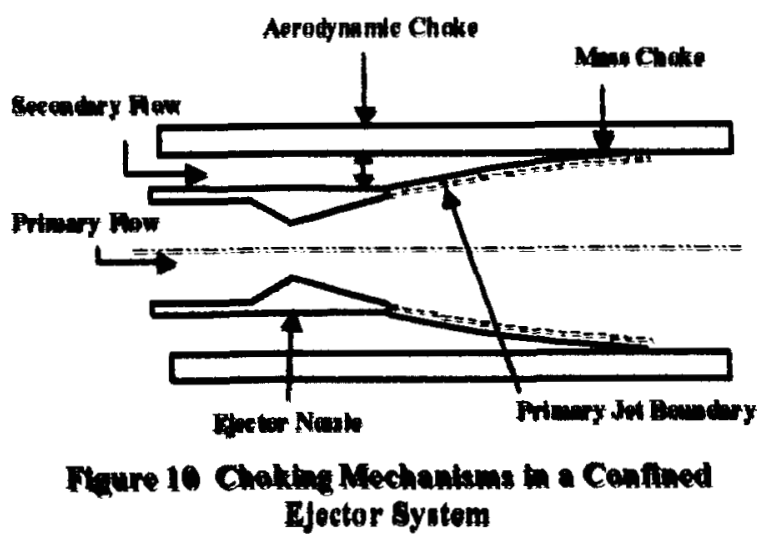

In order to determine the type of chatin mechanism for the UAH ejector freility, the secondary thav static presnures in the minimum geometric area of the strut gap were examined. If the choke in an aerodynamic choke it will cocur in the strut ap regien. Figures 11 and 12 show the ratio of the wall statie pressure to the secondary flow total presmure at each of the ton preseure tap locationa in the itrut gap. All of the chamber prensures tented are ahown on the plow. 


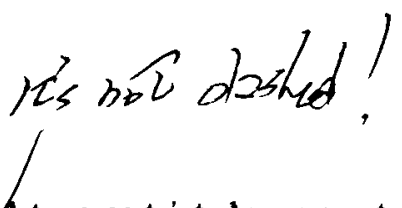

Because of the wale of the plots and the proximity of geveral sete of Anta, uncentainty bars are not shown. The uneertainties for these data points range from $0.5 \%$ to $3.5 \%$. The dahed ling in the figures shows the sonic limit (Ps/Pas $=0.528$ for $y=1.4$ ). A presure ratio at or below this point woulandioute the presenoe of an aeredyamie choke.

Initialy, as the chamber presure is inereased, the strit gap preane ratio deoreace and approaches the sonie limit. When the chamber pressure reaches a value of around 600 poi (aingle nozale) and 350 pai (dual nozzle), the pressure ratio begins to imerease (away from the sonie limit). This mevement away from the senie limit would indicate that the flow in the strut gap is not choked in this region at these higher preasures.

Figures 11 and 12 show presure ratio measured in the two tects of Figs 9 and 10 for chamber presures between 500 and 980 pol. The plot seale is expanded and uncertainty bars have been added. As can be seen, the plat beome vey congeated when uncertainty bars are shown. These plats indioate the flow approaline an aerodynamie choke in the strut gap region when for chamber prosguren around 650 pat, However, as the chamber pressure is inoreased beyond 650 pai the presure ratio obviously begins to inorease away from the sonie limit. At the highest ehamber preseures of each flgure the secondary presure ratio is well above the sonie ratio suggenting

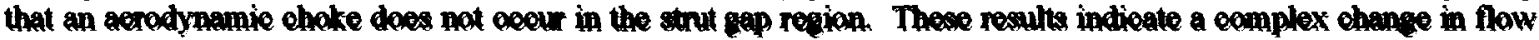
behavior when the driving primary jot prescure inereases between 600 and 700 pei. The mixing duet preseures were next evaluated to help elarify this phemomena.
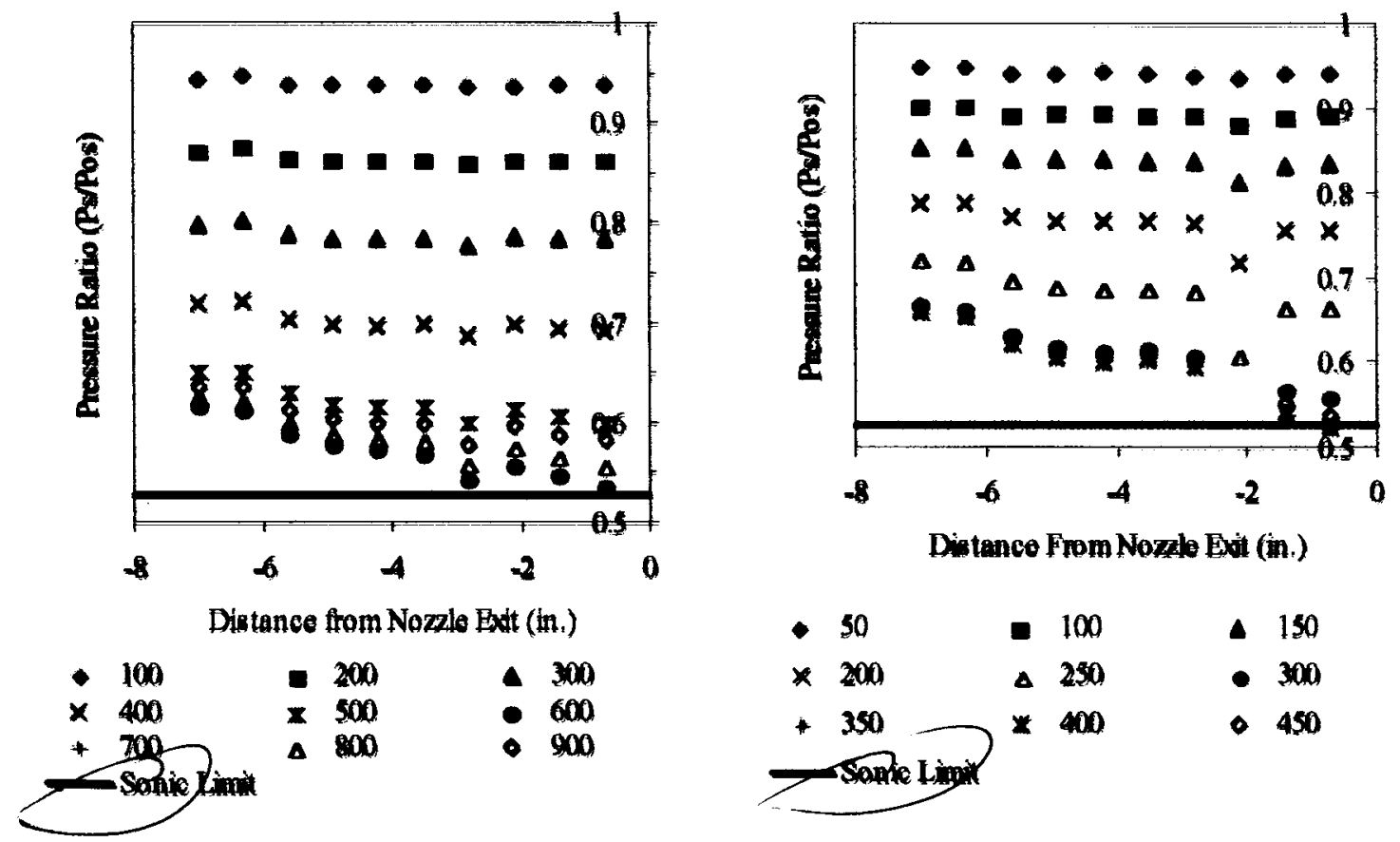

Figure 11 Single Noagle strut Gap Presure Ratlos

Figure 12 Dual Noagle Strut Gap Pressure Ration

For each chamber presure and for both norales the pressure ratio drops the flow approeches the noxale exit plane. From a test to test stand point, as the chamber preseure is inereaned, the atrut gap preseure ratio decreaces and approaches the sonie limit. Whep the ehamber presune reaches value of around 650 pai, the presure ratio beains to increase (away from the nonie limit). This movement away from the sonie limit would indioate that the flow in the stut gap is not ohoked at these higher preanues.

Figures 13 and 14 how preseure ratios measured for the single nozzle otrut at ehamber presure set points

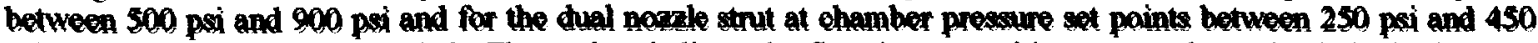
poi. The plot seales are expanded. The plote indiate the flow fo appronehing an aerodynamie choke in the atrut cap repian for chamber presures around 650 pai (single nowle) and 350 pai (dual nozale) However, as the chamber preasure is increased above these values, the pressure ratio obviously beging to inerease away from the 


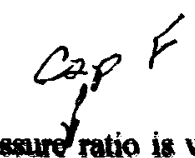

sanic limit. At the highoet chamber preanure of each figure the socandary prosaure ratio is well above the canic ratio suggesting that an aerodynamie ehoke does not oceur in the strut gap region. Co the Dual Nozzle Fig. 14, the pressure ratio appears to reach the sanie limit in the strut gap region however the mevement away from this prenure limit at higher chamber prenfures, while the mass flow remaing conntant (Fig, 4) indicaten that an aerodymamic choke is not present in this regien. The uncertainty bars (if shewn) would indieate that the true value may be above the monle limit. These results do however; indicate a complex change in flow behavior when the driving primany jet presure inereases. The mixing duet presures were next evaluated to help elarify these phonomena.
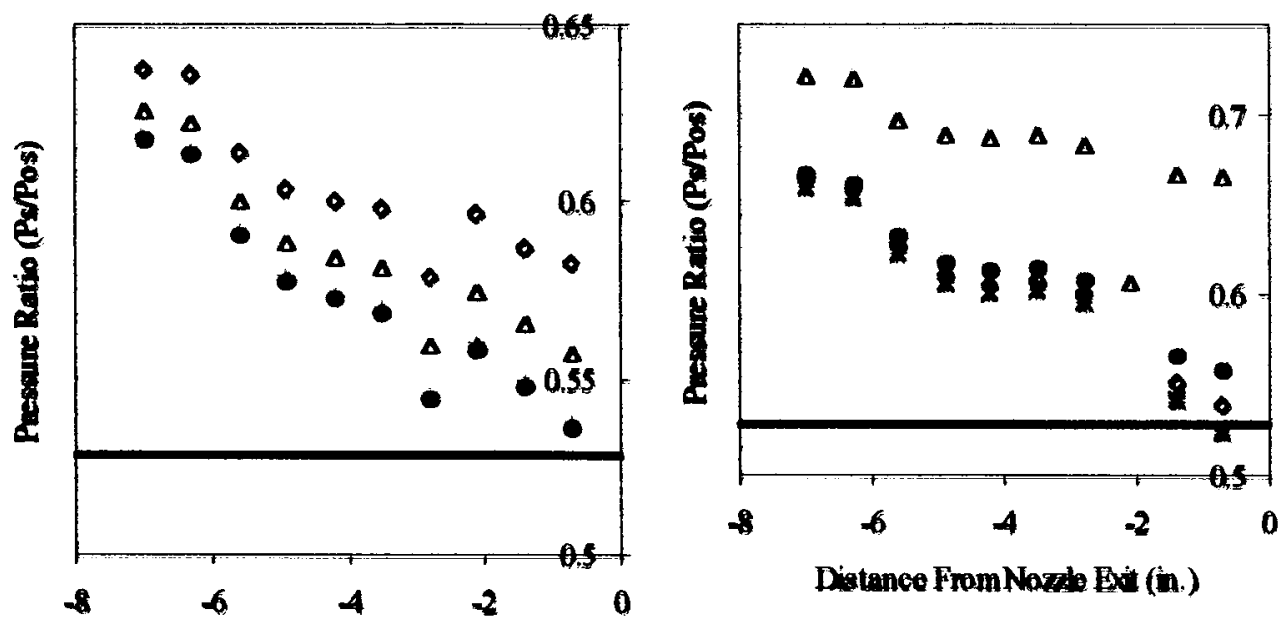

Distance from Nozele But (in.)

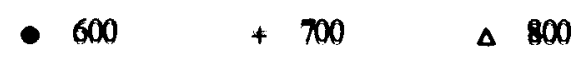

-
$\triangle 250$
- 300
* 350
$* \$$
- 450
Sanic Lim

\section{Figure 13 single Nozzle Strut Gap Pressure Ratios (Higher Chamber Presures Onty)}

\section{Figure 14 Dual Noagle Strut Gep Presure Ratlos (Aleher Chamber Preasures Oaly)}

\section{Mans Flow Calculations}

Figure 4 indicated that the meeondary flow beomes ohoked around a pronure of 500 pai for the single nozzle and 250 pai for the dual nofle At these point Figs 112/4 indieate that the secondary pressure ratios in the sunt gap are not within the monie limit. This suggents that the secondary flow ohoking must be a mass addition ehoke in the mixin duet downstream of the strt. As ehamber presure is inereased there is bitte to no observable change in the mecondary mana flow rate. Thin trend alone does not conclunively prove that the choke doen not ehange from a masa

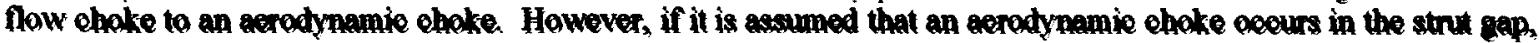
the mase flow rate can be entimated from the secondary flow atagnation temperature and prenure aceording to the elassioal one-dimensional ideal flow equation

$$
m=P a_{*} \cdot A \cdot \gamma \frac{\sqrt{\left(\frac{2}{y+1}\right)^{\frac{\gamma+1}{\gamma+1}}}}{\sqrt{\gamma \cdot R \cdot \mathrm{To}}} b^{n}
$$

where $A$ in the eroms seetional area of the strut gap resion. Based a secondary flow total prensure of approximately $14.7 \mathrm{psi}, \mathrm{Eq}$ (6) produces a maximum mass flow of $3.2 \mathrm{lbm} / \mathrm{s}$ for the secandany flow the mecondary masn flow ehokes with a mass flow equal to $2.3 \mathrm{lbm} / \mathrm{h}$. 
Equation (6) is an idealized equation that yields an order of magnitude value. It neglects many appeets of the flow which may lower the estimates of mase flow suoh as boundary layen, non-uniform veloeity profiles, thermal,

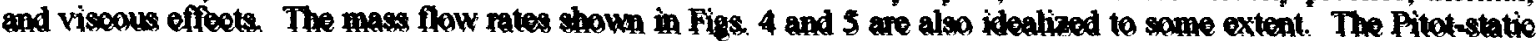
pressure ration were meesured on the duet centerline and used to caleulate a Maeh number. The secondary flow was assumed to be inecmapresible based on the resultant ealeulated Mach numbers that were les than O.3 (sec Fig. 7) The dennity and temporature of the secondary flow to this point were ansumed to be constant. The tomporature was used to caloulate a speed of saund. The speed of sound was then used to obloulate velocity trom Mach mumber. Finally, the socondary mass flow rate was detormined from veloeity and density.

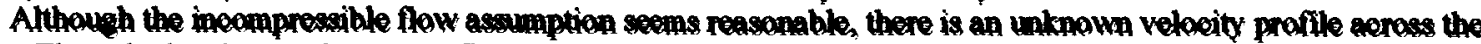
duet. The caloulated sooondary mass flow rate is based on the maximum centerline velocity and is thus somowhat larger than the actual value Even if the napideal nature of the duet flow is geopunted for, the experimentally determined mass flow rate is approximately $2 / 3$ of the theoretical value required for an aerodynamically ohoked flow. Although the strut gap presure ratios indieate slighty inemsistent results, it is believed the secondary flow choking is most likely due to a mass shoke downstream of the rocket exit plane rather than an arodynamic choke in the stout gap.

\section{E. Mixing Section Static Pronuren}

Static preacure measurenents along the centertines of the top and side walls of the duet downstream of the strut exit plane are uned to ovaluate mixing of the primary and secondary flow atroams. Figure 15 ahowa a plot of the top and sidewall pressures for the single nozale stut at a ehamber pressure of 200 pai. Figure 16 shows a plot of the mixing duot presenure dintribution for the dual nozzle atrut at 100 phi chamber presaure (mass flow comparable to 100 psi in the single nowle stul). The presures in the flute have been normalized by dividing by the seondany flow total prenure at the inlet (the lab atmospherie prenture).

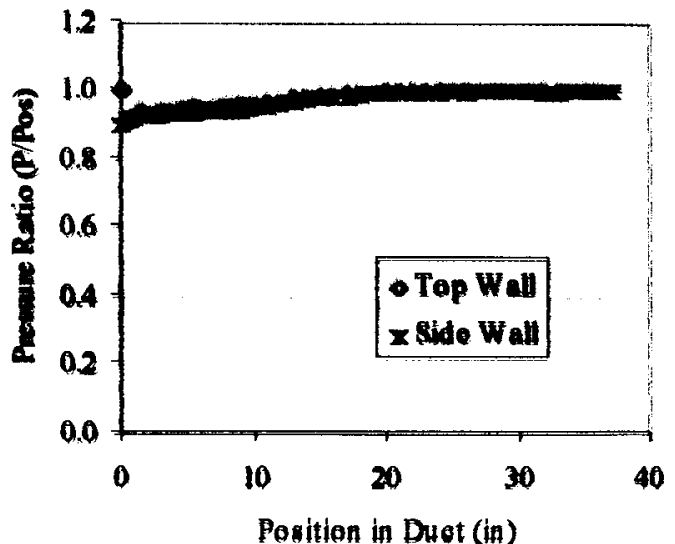

Foure 15: Mining Duct Presunre Diatibution Single Nozzle Strut $(\mathrm{PC}=200 \mathrm{ps})$

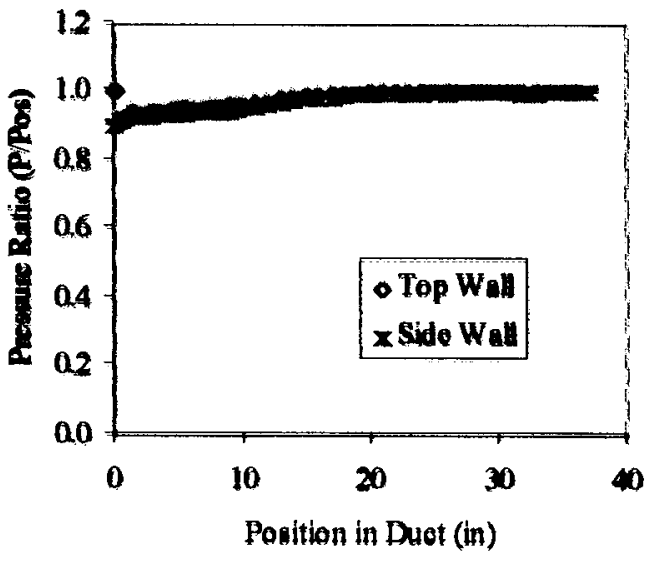

Fure 16 Mintan Duct Prosure Diatributien Dusl Nonsle Strut (Pe $=100 \mathrm{pul})$

As ean be seen in both figures, the side wall prosure at the noale exit starts at a value appraximately equal to the last atrutgap preseure ratio, then gradually recovers. In both caesen, prensure han recovered botween 15 to 20 inehe downstream. The top wall preseure tree shows that initially near the base of the strut there is a region of high preseure as the mecondary flow tries to turn the comer around the strut. This is believed to be a region of separated flow. Appraximately 0.5 inehes dounstrean of the exit plane, the top wall pressure drops sharply to mateh the sidewall preseure and then begine a gradual recovery until it reachen a prenure ratio value near 1 at between 15 to 20 inehes dounstream of the exit plane. These trends were common in bath single and dual nonzle plote for the lower chamber pressures tested (100 to $500 \mathrm{pai}$ for the aingle nozzle, and 50 to 250 pal for the dual monale). For all of these lower presures, the reevery location varied little Tap and side wall presures reovered between 15 to 20 inches downstream of the nozzle exit plane. However, the magnitude of the initial prenure drop inereased with inereasing obamber presure. The presure trees of the top and sidewall trek each other very well. The flow in conaidered to be fully mixed at the point where the two prennures equalize with atmonphoric prenaure, approximately 25 inches downatream. 
For higher chamber preaures $P e>600$ pri (single) and $P 0>300$ pai (dual) the pressure distribution plats showed a different trend. Figures 17 and 18 ahow the mixing duet preseure digtributions for the single nozzle at a chamber pressure of 800 and for the dual noale at a elamber pressure of 400 pei respectively.

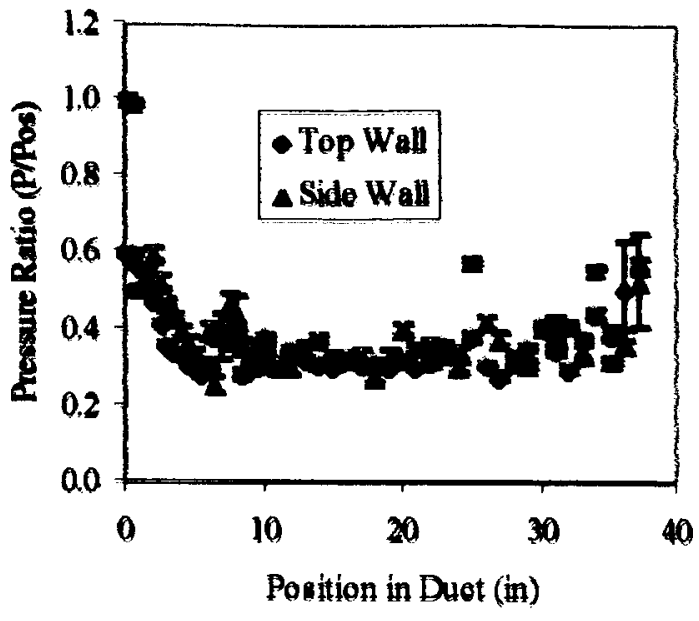

Flaure 17 Eingle Narale Mixing Duet Preaure Distribution (Pe $=8$ eng paid)

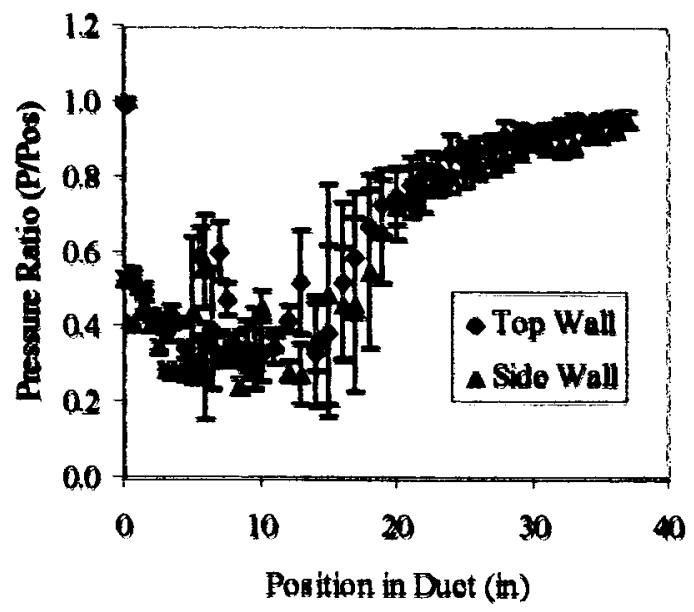

Fqure 18 Dual Nonel Mhing Duct Pressure Diatribution $(\mathrm{Pe}=400$ pal)

In Figures 17 and 18 , the sidowall preseure ratio continuen to decreane after paning the strut exit plane and then

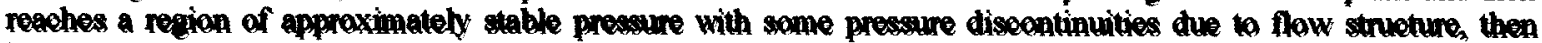
begins to reeover farther downotream. But the mixing length for thene higher chamber prensures is considerably fonger than for the lower presure eases. In beth figures the lop and sidewall pressures do net equalize with atmospheric preseure by the end of the duet. This is an indication of poor flow mixing in the duet. The region of separation within the first half ineh of chet downotream of the strut is still visible in the first two measurements of the top wall preanure trace. In Figure 17, the preseures have junt atarted to recover, however for the dual nozzle strut

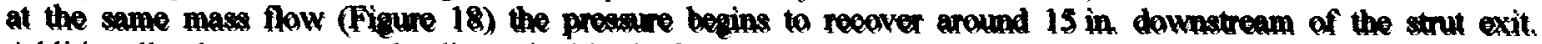
Additionally, there appear to be dicontinuitien in the prenures in the firat 15 inches of the duot. This is partieularly evident in the wall tree. These spikes and dips in presure are attributed to shoek strueture in the duet.

The data in Figure 18 has much larger uncertainty than previoun figurea. This trend was common in the plots with the "high presure" data tread. This lange uneertainty is due to the unsteedines of the flow, rather than traditional uneertainty. Plans are underway for additional tenting with high opeed prenure trannducern to record these turbulent lluetuations.

Because the embedded rocket nozzles are designed for optimum expansion at a chamber prenture around 650 pai at sea level preasure, the change in behavior of the preacure traces was initilly believed to be due to the transition in plume behavior from over expanded to ideal then under expanded." However in light of the dual nowale data, It is believed that this ohange in behavior is due to momentum offects as it coouss around the same mass flow for the dual and single nozzles. For the single nozzle atrut, the transition oceurred between ehamber prensures of 600 psi and 700 pei. For the dual norale strut, this transition coeurs around 350 pai, whieh was one of the ohamber presnures inventigated. At this pressure, both prensure dintribution trendn were recorded in different tosts. In come tests, the transition would ceeur half way through the It is believed that humidity has an influence on the presaure trend as well. On days with high humidity, the "low preseure" data trend would be recorded at a chamber pressure of 350. However, if the humidity wes low, the "high presure" data trend would be reconded.

For the "high pressure" data trend, the duct length required for rocovery to atmonpherie preanure, weems to be a

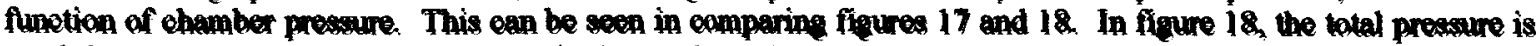
much less than the total preneure for the single nozzle equivalont mam flow (not to be confuned with statio preseure in the mixing duet shown on the plot). As a result, the dual nowale begins to reegver around 15 inches doumetream 
of the noazle exit. while for the single nowie the presture does not begin to recover until much further downetream (approximately 36 inches).

An additional trend was noted in the dual nozle strut presure distributions that was soen in the single nozzle dintributions. This trend eceurred for mid range preseures in the dual nozzle otrut ( $P e=200$ poi -300 pei). Figure 19 and 20 show the mixing duet wall prossure distributions for the single nowle at a chamber pressure of 500 pri, and the dual nozzle at a chamber prensure of $250 \mathrm{pat}$

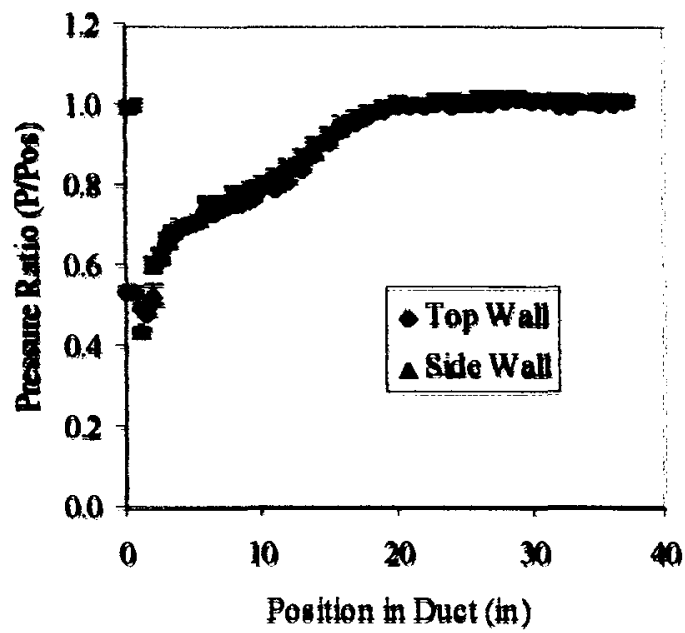

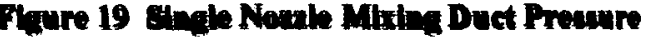 Distribution (Pe $=6$ pat).

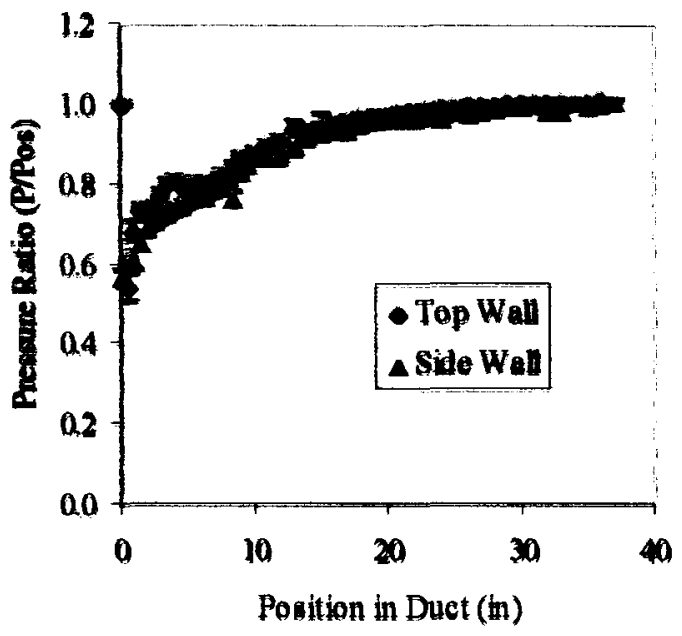

Prure 20 Dual Noale Mlethg Duet Presure Pronle (Pe = 399 pal)

In Figure 20, thore is a "hump" in the top wall preseure diatribution that oceure approximately 4 inches downstream of the exit plane. This "loupp" appears at 250 pai, and becomes more pronounced until the pressure distribution trond change oecurs around 350 pal. This hump is not present in the single nozzle premure profiles of equivalent mass flow, and is believed to be due to the nowlo geometry effects (2 monales as opposed to 1 nowale).

\section{Conclualons}

This paper presents the results of a series of tests on a single novale and a dual nowale stont based ejector. The tents were conduoted at various primary chamber preseure eetpointa ranging from 100 to 900 poi (single nozzle) and

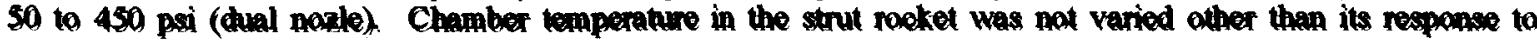
chamber prensure an an ideal gas. Lab atr at atmosphorie preanure was drawn through a contoured inlot into the duot. Secondary and mixing duet exit, Mach numbers were determined from Pitotstatio prabe measurements Mixing duet statio presnure distributions were alno moasurod. Fluid bohavior in the duot was examined with foeus on mixing of the flow streans, chaking meehanisms of the sechdary flow stream, mass flow entrainment.

\section{A. Mass Flow Augmontation}

A ehole of the seondary mass flow was demonstrated at a chamber preseure of 500 psi and 250 per for the single and dual nozzlo ojectors respectively. This corrosponds to a primary mans flow of approximately $2 \mathrm{lbm} / \mathrm{mec}$ in both ejeotor. Fram the examination of stutgap and duet wall statie pressure proffles it was cencluded that the type of choke whieh oecuri in the duet for all of the pronsuren examined wan a masn choke rather than a traditional aendynamic choke. Athough around some chamber pressures the pressure ratios in the strut gep region appear to approach the preneure ratio indicating an aerodynamio choke, the consintent value of the necondary mans flow which is 33\% less then the theoretioal value for an acodynamic ohake indioates that the mass oheke is still present and that the aerodynamie ohoke is nover truly reached.

Ratios of secondany to primary mas flow rate were ìvestigated a funotien of primary to secondary flow total prensure ratio. Secondary total presure remainod constant ainoe the induced flow was entrained from ambient laboratory conditions. The largest mass flow aumentation cocured at the lowest primary total prosure setpoints. 


\section{5}

As primary total presaure increased primary and secondery mass flow bath inereased until the secondpry mass flow choked. Ptimary man flow continued to inorease with inoreasing setpoint presoure, while secondfry man flow remained canstant after the choking paint. This caused the mass how ratio to deorease sherply.

The secondary flow choked at correnponding Mach number of 0.3 and a primary chamber prenure of approximately 500 pri (single nowale) and 250 psi (dual nozkle). Mixing duet exit Mreh number were determined and found to reach a sonie exit eore flow for ohamber pressures above 700 psi (ningle nozzle) and 350 pai (dual nowale). In general, the exit Mach numbers were lesan expected, and may be atributed to the enhaneed mixing and three-dimenaional effeets of the anymmotrie geometry, or losses in the long the mixing duet.

\section{B. Minine Duct Presune Diatributions}

Two distinet patterne were vinible in the preneure distribution plots of the mixing duet. For chamber preasuren betow 700 psi (single nanke) and 350 pai (dual nonle) the pressure traverses along the duet top and sidewalls revealed a posible top wall recirculation zone within the firat 0.5 inehes of the duet followed by a sharp deerease in pressure ratio. The minimum presure ratios for top and sidewalls deerease with inereasing primany drivin pressure. The sidewall prensuren in the region between 5 and 10 inchon oxhibit a significant dip in comparion to

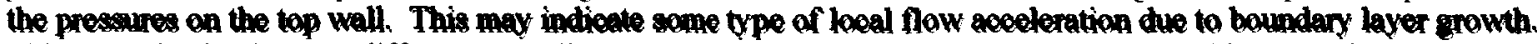
This may also be due to a different spreading rate of the mupernonic core flow toward the sidewalln of the duet than towand the top and bottom wells.

For chamber preseures at or above 700 poi (single) and 350 pai (dual), the prensure traces revealed the mame

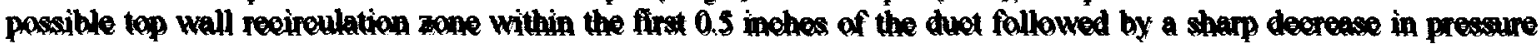
ratio. This was followed by a more gradual pressure ratio drop to a value equal to approximately 0.3 . This preseure

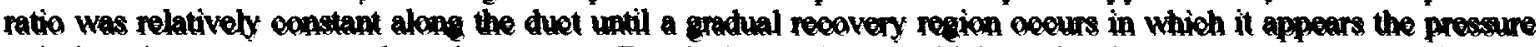
ratio is trying to recover to the exit presnure. For aingle nozzle at the higheat ehamber preasures recorded, the duct does not appear to be lans enough for the presture to fully recover to atmospherie conditions. This is indication that at these high prenfure ratios, the duet exhibits poor mixing between the necondary and primary flow atreams. The higher ehamber pressure plats also indicate the presence of stook strueture in the duet evidenced by sharp discontinuities in the presesure ratios.

\section{Comparian to Previous Studles}

Comparions to previous UAH PRC cold-flow mixing studies of a two-nozale configuration providod insight

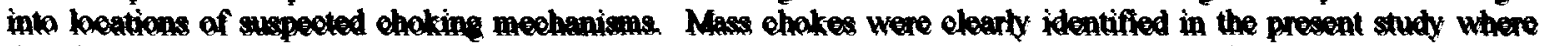
they had not been in previous studies. Data was reconstruoted from the twin nozzle studies in order to identify chaking paints. Athough unoertainty information was lacking, it was coneluded that the secondary flow ehakes at approximately the ame primary mase flow rate for both the twin and aingle nozzle configuration an found in the present study. However, the rol presure for the two naxales is half that of the single nowle This is consistent with momentum similarity.

Results from the prewent atudy were compared to hot-fire reaults obtained in tosta at the PSU Propulsion Fngineering Research Center" The PSU gjector investigations included both a single and twin strut rooket canfiguration. The cenchusians from PSU twin thruter tess sugested that the mixing length is a function of the number of atrut roekots. However, the present cold-flow atudy nhow that the mixing length in the duet is almo a signifieant function of primany mass flow (and heace ehamber pressure). The twin roket sudy at PSU shows an enhancement in the entrained mans flow over the aingle thruter configuration. However, in light of the present investigation of choling meohanisms, this effeet is only tre if the nondes are operated betow the mass addition choke threahold. Had the primary pressure of the single and twin thruters been operated above this threahold, it is believed that entrained mas flow properties would be the seme regardless of the number of thrusters employed.

\section{References}

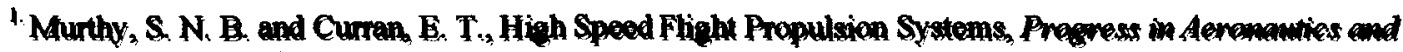
Astronautles Vol, 137, 1991.

3. Siebenhaar, A, and Bulman, M. J., The Strutiet Bnoine: The Overlooked Option for Space Launeh in 31/st ALAA/ASME/SAE/ASEE Joint Propulsion Conferenee and Exhlbit American Intitute of Aeronaution and Astronautios, San Diego, Califonia, 1995.

${ }^{3}$ Muller, S. Bakker, P., Hawk. C., Parkinean. D, and Turner, M. Mixing of Supersonie Jets in a Strutjet Propulsion Syatem, Jenumal of Prepulvien and Power vol. 17 (No. 5), 1129-1131, 2001.
} 
4. Parkinson, D., Tumer, M., and Wamer, D., Mixing of Superanic Streams, in 3Sth ALAA/ASMESAE/ASEE Joint Propulsion Conforom and ExhibiLos Angoles California 1999.

9. Mullor, S., Hawk, C., Parkinmon, D. Tumer, M., and Bakker, P, O., Mixing of Superanie Jets in a RBCC Strujet Propulnion Syotem, in 35th AIAAASME/SAE/ASEE Jolnt Propulsion Conferenee and ExhibitLon Angelen, California. 1999.

"Landrum, D. B., Thames, M., Parkineon, D., and Gautney, S., Investigation of the Roeket Induced Flow Field

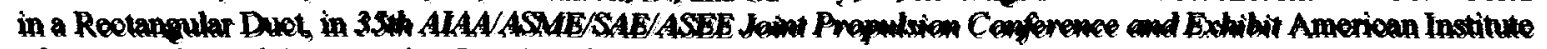
of Aoranauties and Astronautice, Lo Angeles, Califomia, 1999.

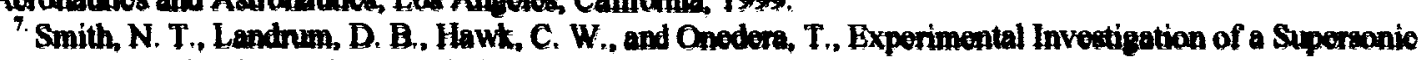
Non-Axirymmetrio e Ejoctor, in 10 th AIAANAL-NASDA-ISAS Intermational Space Planes and Hypersonte Systems and Technalagien Conforence American Institute of Aeronauties and Astronauties, Kyoto, Japan, 2001.

- Smith. N. T. An Experimental Imestigation of a Nom-Axisymmetric Supersonic Cold-Flow Ejector. University of Alabama in Huntoville, 2002.

'. Lineberry, D.s Landrum, D. B. Hawk, C., and Smith. N. T., Characterization of Cold Flow NonAxisymmetrie Ejectors, in 39th ALA /ASMEE/SAE/ASEE Jolnt Propulsion Conferenee and Exhibit, AIAA, Ino, Huntwille, Alebama, 2003.

10. Fabri, J. and Sientrunck, R, Supersonic Air Ejectors Academic Prese. Now York, Now York. 1958.

11. Fabri, J. and Paulon. J., Theary and Experiments on a Superenic Air-To Air Ejectons 1956.

12. Cramer, J. M., Greene, M. Pal, S, and Santora R. J, RBCC Ejector Mode Operating Characteristiog for single and Twin Thruster Conflguration, in 37th AIAA/ASMESAE/ASEE Joint Propulsion Conference and Exhlbit Amerioan Intitute of Aeronautios and Astromauties, Salt Lake City, Utah, 2001. 